\title{
SPEECH ACT ANALYSIS OF DR. ZAKIR NAIK'S SPEECH ON YOUTUBE CHANNEL ENTITLED: DOES GOD EXIST
}

\author{
Nurbaeti Alawiyah', Iman Santoso ${ }^{2}$ \\ ${ }^{1}$ IKIP Siliwangi \\ ${ }^{2}$ IKIP Siliwangi \\ ${ }^{1}$ alawiyahnurbaeti97@gmail.com, ${ }^{2}$ ImanSantoso515@gmail.com
}

\begin{abstract}
This research aimed to explore and identifying speech acts uttered by Dr. Zakir Naik in his standing dawah on the youtube channel entitled: Does God Exist. The research shows that factors of situation, place, topic, speaker, and context play an important role in analyzing speech act. The form of the speech has a representational function to inform and invite people. In this study, researchers used descriptive qualitative methods. The collect data, the writers used several steps. First, download the video on the internet. Second, transcript the dialogues into the texts. Third, reading the conversation texts. After that, identifying the sentences of Dr. Zakir Naik's speech. Then, counting the sentences includes a speech. And the last, describing the reason why the sentences include speech act. In which researchers examined naturally in every speech act that occurred in the theory stated by Yule (1996) in his theory about the types of speech acts divided into representative, directive, commissive, expressive, and declarative. In this study, the researchers found 13 utterances as a representative, 7 utterances as a directive, 2 utterances as a commissive, 2 utterances as a declarative, and not found expressive contained in the speech Dr. Zakir Naik's entitled: Does God Exist.
\end{abstract}

Keywords: Speech Act, Pragmatic, Zakir Naik, Does God Exist, Speech

\section{INTRODUCTION}

A language is a tool for communication between humans. As for Kiuk \& Ghozali (2018), with that humans communicate with each other using language, then language is a tool for communication in which all human activities are inseparable from language. a language is a tool for communicating forms of verbal communication used by humans to communicate and convey their intentions, as written language and spoken language. one of the languages that can be used is speech acts (Yule, 1996:5 in Kiuk \& Ghozali, 2018). Cited by Santoso, Sujatna, \& Mahdi (2014), the function of language is as a work of personal language, in which the speaker expresses an attitude towards what is presented. the point is that speakers not only express emotion through language but to show it when it can convey emotions.

According to Richards \& Schmidt (2010) in Andriyani (2016), linguistics has several branches, namely: Phonetic is the study of speech sound (articulated), Phonology is the study of speech and functioned, Morphology is the study of formation word (grammar), Syntax is the study of words order (form sentence), Semantic is the study of meaning, Pragmatics is the study of language use, Psychology of psychology, Socio-linguistics is social, Neurolinguistics is the brain, Discourse Analysis is approaches and analyzes (writing and spoken), Applied Linguistics is item and identifies, Computational Linguistics is the theoretical linguistics.

In this case, the researches only discussed the study of language use or usually called pragmatics, with the object of study from pragmatics, namely speech act. According to Tutuarima, Nuraeningsih, \& Rusiana (2018), pragmatics is a branch of linguistic science that 
discusses what belongs to the structure of language as a communication tool between speakers, listeners and refers to the signs of language being discussed. As for Yule (1996:3), pragmatics is a field that examines the meaning of speakers, meaning according to context, meaning are spoken, meanings communicated or communicated by speaker, and forms of expression according to the social distance that limit the participants involved in certain conversations.

The object of this pragmatic study in this researchers will discuss the actions in a speech, namely the speech act. The speech act is the further action of the words as Yule (1996) in Wijaya \& Helmie (2019) stated, the speech act is the action of using language. Because the speech act will be very interesting to do. According to Austin (1962) in Mufiah, Yazid, \& Rahman (2018), distinguishes three types of actions that are related to speech, namely: speech act locution, speech act illocution, and speech act perlocution. While Searle in Wulandari et al., (2015), stated that a speech act can be categorized into 5 types, namely: (a) representative is a speech act that binds the speaker to the truth on what he has said (tells something true), for example stating, reporting, showing, and mentioning. (b) a directive is a speech act carried out by the speaker with the intention that the listener can take the action mentioned in his speech (asking the listener to do something the speaker wants), for example telling, pleading, demanding, suggesting, challenging. (c) commisive is a speech act that is done with the intention that the words are interpreted as an evaluation of the things mentioned in the utterance (assessing), for example praising, saying thank you, criticizing, complaining. (d) expressive is a speech act that binds the speaker carried out what is stated in his words (emphasizing certainty), for example promising, swearing, and threatening. (e) declarative is a speech act that is performed by the instructor to create something (status, circumstances and so on) that is new or changes the world, for example deciding, canceling, prohibiting, allowing, and forgiving.

To obtain the types of speech act, the researchers found one oral or written communication whether it's a monologue or dialogue. The conversation is a source for getting the type of speech act, through conversation. The researchers analyzed the speech that becomes the target's meaning. The researcher analyzed the speech act to understand in-depth the meaning of what the speaker said.

The researchers are interested in trying to research the speech act that has been said by Dr. Zakir Abdul Karim Naik or better known as Dr. Zakir Naik is a doctor who graduated from the Univesity of Mumbai majoring in Medical sciences and earned a Bachelor of Medicine become a preacher. Dr. Zakir Naik is known for his ingenuity when preaching, and there are so many speech acts that can be examined in every word Dr. Zakir Naik says. His dawah videos are also widely distributed on various social media networks. One of Dr. Zakir Naki's videos is uploaded by the YouTube channel Sadnex1, entitled Does God Exist. In at youtube channel, many videos of Dr. Zakir Naik's are preaching.

Besides, to the pragmatic field, the researchers liked his delivery when preaching, because his preaching was very giving a lot of insight and could also add knowledge, the researcher's point of view, interest, and curiosity through his dawah, the researchers analyzed the speed act in his preaching in data.

Based on these reasons, the researchers decided to found out and analyzed the types of speech act and classification of speech act proposed by (Yule, 1996) and (Searle, 1997) in their speech act theory. The researchers, in this case, want to state the following statement as being investigated for further study. They can formulate as follows: 
1. What kind of speech act occurs in the speech of Dr. Zakir Naik in youtube channel sadnex1, Does God Exist video?

2. What is the classification of the speech act in the speech of Dr. Zakir Naik in youtube channel sadnex1, Does God Exist video?

3. What are the underlying reasons for the speech act in the speech of Dr. Zakir Naik in youtube channel sadnex1, Does God Exist video?

Then, the purpose of the study intends to find out the following description.

1. To find the type of speech act and indirect in the speech of Dr. Zakir Naik in youtube channel sadnex1, Does God Exist video.

2. To find a classification speech act representative, communicative, expressive, declarative, and directive in the speech of Dr. Zakir Naik in youtube channel sadnex1, Does God Exist video.

3. To find the reasons underlying the speech act in Dr. Zakir Naik's speech in youtube channel sadnex1, Does God Exist video.

\section{METHOD}

In this study, the researchers used descriptive qualitative. According to Bogdan \& Taylor in Moleong (2017), argue that leather studies are procedures that produce descriptive data in the form of written or oral; words from the people or actors observe. This research is analyzed naturally in each speech act that occurs based on the theory put forward by Yule, 1996 in Praditya, Dwi Jaya I Made, Putra \&, Artini (2014) in his theory of the type of speech act to be representative, directive, commissive, expressive, and declarative. While a data source in this study from the internet, especially youtube. The stages of writer use in this research are: 1) Downloading Dr. Zakir Naik's speech on youtube, at https://youtu.be/ypguOLjx35k. 2) Print out the speech text. 3) Reading the speech text. 4) Identify the sentences of Dr. Zakir Naik's speech contains a speech act. 5) Counting the sentence which includes speech act. 6) Explain the reason why sentences include a speech act.

\section{RESULTS AND DISCUSSION}

\section{Results}

Classification of the form and function of the speech act Dr. Zakir Naik's speech, the table below:

Table 1.

Types of speech act

\begin{tabular}{cc}
\hline Types of Speech Act & Utterance \\
\hline Representative & 13 \\
\hline Directive & 7 \\
\hline Commisive & 2 \\
\hline Declarative & 2 \\
\hline Total & $\mathbf{2 4}$ \\
\hline
\end{tabular}

Revealed in from table 1. Found that there are 13 utterances as representative types, 12 utterances as a directive types, 3 utterances as a commisive type, 2 utterances as a declarative, and not found utterance of expressive. 


\section{Discussion}

Here is the interpretation of the result above:

\section{Representative}

Dr. Zakir Naik's speech test in answering the question of a questioner on the da'wah program on the YouTube channel Sadnex1, "Does God Exist" is described and classified in the table below:

Table 2.

Representative Classification and Function of Dr. Zakir Naik's Speech

\begin{tabular}{|c|c|c|c|c|}
\hline No & Speech & Form & Function & Note \\
\hline 1 & $\begin{array}{l}\text { The Christian, he is } \\
\text { Christian because his } \\
\text { father is Christian. The } \\
\text { person is Hindu } \\
\text { because his father is } \\
\text { Hindu. The most of } \\
\text { Muslims because their } \\
\text { father are Muslim. This } \\
\text { atheist is thinking, his } \\
\text { father (his parents) may } \\
\text { be religious, but he } \\
\text { does not believe in the } \\
\text { gods which his parents } \\
\text { warship. }\end{array}$ & Representative & Stating & $\begin{array}{l}\text { In the example besides the } \\
\text { speaker trying to convey } \\
\text { what they want and making } \\
\text { words following the world } \\
\text { (belief). The speaker } \\
\text { explained, the Speaker } \\
\text { stated, "A Christian, he is a } \\
\text { Christian because his father } \\
\text { is a Christian. That person is } \\
\text { a Hindu because his father is } \\
\text { a Hindu ..." here the speaker } \\
\text { states the truth with what the } \\
\text { speaker found. }\end{array}$ \\
\hline 2 & $\begin{array}{l}\text { Whatever they say it } \\
\text { will be the same or } \\
\text { similar. Either they say } \\
\text { the creator, the } \\
\text { manufactural, the } \\
\text { producer, the inventor, } \\
\text { it will be the same or } \\
\text { similar. So the atheist } \\
\text { will tell us, that } \\
\text { initially, there was a } \\
\text { primary nebula... Then } \\
\text { there was a big bang, } \\
\text { there was a secondary } \\
\text { separation. } \\
\text { gives rise to galaxies, } \\
\text { the sun, the moon, and } \\
\text { the earth in which we } \\
\text { live. This we call the as } \\
\text { big bang. }\end{array}$ & Representative & Stating & $\begin{array}{l}\text { In the example besides the } \\
\text { speaker stating what he } \\
\text { wants to say and making } \\
\text { words following the world } \\
\text { (belief), as the speaker said } \\
\text { in a brief explanation "that } \\
\text { an atheist tells us that the } \\
\text { world begins with primary } \\
\text { nebulae and there is a } \\
\text { separation of brothers. called } \\
\text { the big bang. " which } \\
\text { sentence includes the } \\
\text { speaker's statement } \\
\text { following the world (belief). }\end{array}$ \\
\hline 3 & $\begin{array}{l}\text { But what you are } \\
\text { talking about big bang } \\
\text { is already mentioned in } \\
\text { Quran, in SORAT } \\
\text { ANBIA (Chapter }\end{array}$ & Representative & Showing & $\begin{array}{l}\text { The example besides stating } \\
\text { that the speaker stated with } \\
\text { confidence in which the } \\
\text { speaker showed a statement } \\
\text { that "in the Qur'an has }\end{array}$ \\
\hline
\end{tabular}




\begin{tabular}{|c|c|c|c|c|}
\hline & $\begin{array}{l}\text { number } 21 \text { verse } \\
\text { number } 30) \text { "Do not the } \\
\text { unbeliever see... that } \\
\text { the heavens and the } \\
\text { earth were joined } \\
\text { together and we clove } \\
\text { them asunder." }\end{array}$ & & & $\begin{array}{l}\text { explained about what is the } \\
\text { big bang that has been } \\
\text { mentioned in the letter Anbia } \\
\text { verse } 30 \ldots \text { in this statement } \\
\text { the speaker can state what he } \\
\text { wants to say according to } \\
\text { what he believes. }\end{array}$ \\
\hline 4 & $\begin{array}{l}\text { The Arabic word used } \\
\text { for moonlight in the } \\
\text { Quran is (MONEER or } \\
\text { NOOR).. meaning } \\
\text { reflected light or } \\
\text { borrowed light. that the } \\
\text { light of the moon is not } \\
\text { its own light but } \\
\text { reflected light which } \\
\text { we have come to know } \\
\text { recently. The atheist } \\
\text { will tell you: Its } \\
\text { spherical. So he will } \\
\text { tell us: its was } 1579 . \\
\text { When Ferdinand when } \\
\text { he sale around the } \\
\text { earth, that he proved } \\
\text { that the earth was } \\
\text { spherical. But the } \\
\text { Quran said } 1400 \text { years } \\
\text { ago... }\end{array}$ & Representative & Stating & $\begin{array}{l}\text { Based on the statement } \\
\text { besides, the researcher found } \\
\text { a speech act that was } \\
\text { representative (Stating). } \\
\text { This representative (Stating) } \\
\text { appears in the sentence "The } \\
\text { Arabic word used for } \\
\text { moonlight in the Quran is } \\
\text { (MONEER or NOOR)..." in } \\
\text { this sentence, it states that } \\
\text { the speaker knows if the } \\
\text { sentence shows something } \\
\text { following the world (belief). }\end{array}$ \\
\hline 5 & $\begin{array}{l}\text { When I was in school, I } \\
\text { had learned that the sun } \\
\text { was stationary, it } \\
\text { revolved but did not } \\
\text { rotate around its own } \\
\text { axis. I say: "No, that's } \\
\text { what I had learned in } \\
\text { school and I pass my } \\
\text { school in } 1992 . \\
\text { Approximately } 12 \\
\text { years back. I had } \\
\text { learned the sun was } \\
\text { stationary, did not } \\
\text { rotate around its own } \\
\text { axis." }\end{array}$ & Representative & Stating & $\begin{array}{l}\text { Based on the statement } \\
\text { besides, the researcher found } \\
\text { a speech act that was } \\
\text { representative (Stating). } \\
\text { This representative (Stating) } \\
\text { appears in the sentence " } \\
\text { When I was in school, I had } \\
\text { learned that the sun was } \\
\text { stationary, it revolved but } \\
\text { did not rotate around its own } \\
\text { axis" in this sentence, it } \\
\text { stated that the speaker knows } \\
\text { if the sentence shows } \\
\text { something following the } \\
\text { world (belief). }\end{array}$ \\
\hline 6 & $\begin{array}{l}\text { The only reply the } \\
\text { atheist can give you is } \\
\text { the creator, the } \\
\text { Cherisher, the } \\
\text { manufacturer, the } \\
\text { inventor, the producer. }\end{array}$ & Representative & Stating & $\begin{array}{l}\text { Based on the statement } \\
\text { besides, the researcher found } \\
\text { a speech act that was } \\
\text { representative (Stating). } \\
\text { This representative (Stating) } \\
\text { appears in the sentence "This }\end{array}$ \\
\hline
\end{tabular}




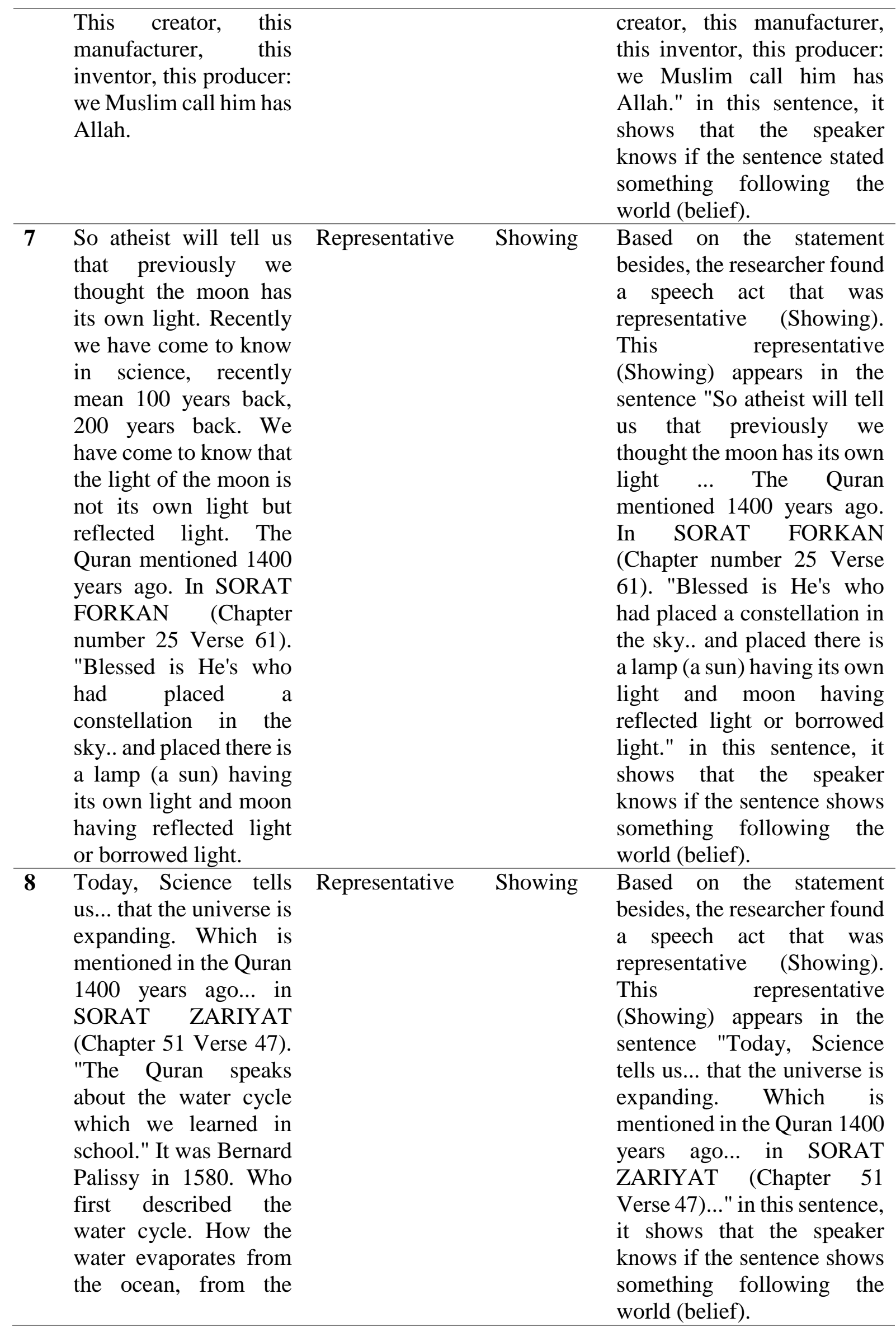


clouds, move in the

interior... fall as rain.

9 Quran says in SORAT Representative Showing Based on the statement

TAHA (Chapter 20

besides, the researcher found

Verse 53). That the

plants have got sexes:

Male and Female.

Today, we have come

to know that there are

two types of water.

Sweet and Salty, and

there is a barrier

between them. Which

is mentioned in the

Quran... In SORAT

FORQAN (Chapter 25

Verse 53), and In

SORAT RAHMAN

(Chapter 55 Verse 17-

18). It is Allah who has

let free two bodies of

flowing water, do they

meet, they will not mix.

There is a barrier

between them.

a speech act that was representative (Showing).

This representative

(Showing) appears in the sentence "Quran says in SORAT TAHA (Chapter 20 Verse 53). That the plants have got sexes: Male and Female. Today, we have come to know that there are two types of water. Sweet and Salty, and there is a barrier between them. Which is mentioned in the Quran... In SORAT FORQAN (Chapter 25 Verse 53), and In SORAT RAHMAN (Chapter 55 Verse 17-18)...." in this sentence, it shows that the speaker knows if the sentence shows something following the world (belief).

10 Which is mentioned in Representative Showing the Quran 1400 years Based on the statement ago... In SORAT NABA (Chapter 78 Verse 6-7). The Quran speaks about biology, that we have created every living creature from water, every living thing... In SORAT ANBIA (Chapter 21 Verse 30). Quran mentioned this 1400 years ago. The Quran speaks about Zoology, about the lifestyle of spider, In SORAT ANKABOOT (Chapter 29 Verse 41). besides, the researcher found a speech act that was representative (Showing). This representative (Showing) appears in the sentence "Which is mentioned in the Quran 1400 years ago... In SORAT NABA (Chapter 78 Verse 67). The Quran speaks about biology, that we have created every living creature from water, every living thing..." in this sentence, it shows that the speaker knows if the sentence shows something following the world (belief).

About Ant In SORAT

NAML (Chapter 27

Verse 17-18). About the Bee In SORAT 
ROME (Chapter 16

Verse 66, 68, 69). The

Quran speaks about

Embryology

In

SORAT

ALAQ

(Chapter 96 Verse 1-2).

11 The Quran speaks about the Embryologic stage In SORAT Representative Showing

Based on the statement besides, the researcher found MOMENON (Chapter 23 Verse 12-14). You can go on talking about Scientific points, there are more than a thousand verses in the Quran which speaks about science.

a speech act that was representative (Showing). This representative (Showing) appears in the sentence " The Quran speaks about the Embryologic stage In SORAT MOMENON (Chapter 23 Verse 12-14)..." in this sentence, it shows that the speaker knows if the sentence shows something following the world (belief).

12 What you are talking Representative Mentioning about big bang is Based on the statement already mentioned in the Quran 1400 years ago. besides, the researcher found a speech act that was representative (Mentioning). This representative (Mentioning) appears in the sentence "What you are talking about big bang is already mentioned in the Quran 1400 years ago..." in this sentence, it shows that the speaker knows if the sentence shows something following the world (belief).

13 This water cycle spoke Representative Reporting Based on the statement about in great detail in besides, the researcher found the Quran in several a speech act that was verses. representative (Reporting). This representative (Reporting) appears in the sentence "This water cycle spoke about in great detail in the Quran in several verses..." in this sentence, it shows that the speaker knows if the sentence shows something following the world (belief). 
2. Directive

Dr. Zakir Naik's speech in the form of a directive was described in the data table below:

Table 3.

Directive Classification and Function of Dr. Zakir Naik' Speech

\begin{tabular}{ll}
\hline No & \multicolumn{1}{c}{ Speech } \\
\hline 1 & The first question I ask \\
to the atheist is: that \\
suppose that there is an \\
equipment, there is \\
machinery which no \\
one in the world have \\
ever seen before. If it's \\
brought in front of you. \\
If it brought in front of \\
the atheist.
\end{tabular}

Form Function Note

Directive Demanding

Based on the statement of speakers beside, the researcher found a speech act that was directive (Demanding). This directive (Demanding) appears in the sentence "... that suppose that there is an equipment, there is machinery which no one in the world have ever seen before. If it's brought in front of you. If it brought in front of the atheist." In the researcher's opinion of the study is the clause uttered reflects the gratifying of the speaker. This sentence is included in the direction because it gives the listener a demand, with the speaker demanding an answer about the listener's knowledge in the creation of the universe.

\begin{tabular}{|c|c|c|c|c|}
\hline 2 & $\begin{array}{l}\text { Just keep at the back in } \\
\text { your mind. Then ask } \\
\text { him this question. That } \\
\text { how did our universe } \\
\text { come to existence? }\end{array}$ & Directive & Telling & $\begin{array}{l}\text { Based on the statement of } \\
\text { speakers beside, the } \\
\text { researcher found a speech } \\
\text { act that was directive } \\
\text { (Telling). This directive } \\
\text { (Telling) appears in the } \\
\text { sentence "Just keep at the } \\
\text { back in your mind. Then ask } \\
\text { him this question. That how } \\
\text { did our universe come to } \\
\text { existence?" In the } \\
\text { researcher's opinion of the } \\
\text { study is the clauses uttered } \\
\text { reflects the gratifying of the } \\
\text { speaker. This sentence } \\
\text { included directive because it } \\
\text { tells how the universe exists. }\end{array}$ \\
\hline 3 & $\begin{array}{l}\text { When did we come to } \\
\text { know about this } \\
\text { creation of the } \\
\text { universe? }\end{array}$ & Directive & Demanding & $\begin{array}{l}\text { Based on the statement of } \\
\text { speakers beside, the } \\
\text { researcher found a speech } \\
\text { act that was directive }\end{array}$ \\
\hline
\end{tabular}




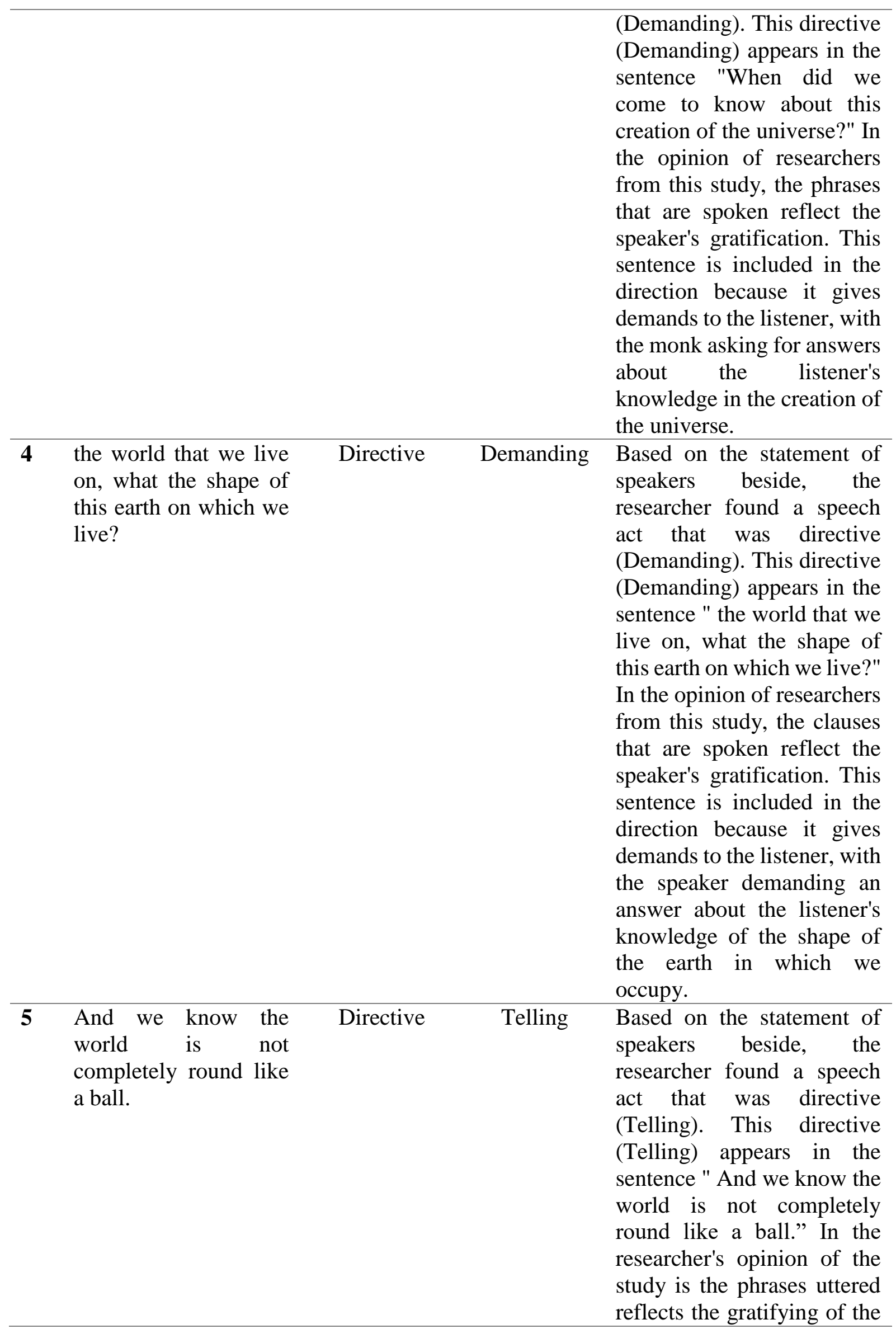


speaker. This sentence is included in the direction because it tells the listener, with the speaker telling him that the earth is not completely round like a ball.

\begin{tabular}{l}
\hline Who could have Directive Demanding \\
mentioned 1400 years \\
ago that the shape of \\
the earth is geo \\
spherical?
\end{tabular}

Based on the statement of speakers beside, the researcher found a speech act that was directive (Demanding). This directive (Demanding) appears in the sentence " Who could have mentioned 1400 years ago that the shape of the earth is geo spherical?" In the opinion of researchers from this study, the clauses that are spoken reflect the speaker's gratification. This sentence is included in the direction because it demands the listener, with the speaker demanding who can name the shape of the earth as geo spherical.

7 So the atheist will say:

"Is that mentioned in the Quran?!" So the Quran says that: besides the sun revolving it even rotates about its own axis. Who could have mentioned this in the Quran 1400 years ago?

$\begin{aligned} & \text { Directive Demanding } \text { Based on the statement of } \\ & \text { speakers beside, the } \\ & \text { researcher found a speech } \\ & \text { act that was directive } \\ & \text { (Demanding). This directive } \\ & \text { (Demanding) appears in the } \\ & \text { sentence "... So the Quran } \\ & \text { says that: besides the sun } \\ & \text { revolving it even rotates } \\ & \text { about its own axis. Who } \\ & \text { could have mentioned this in } \\ & \text { the Quran 1400 years ago?" } \\ & \text { In the opinion of researchers } \\ & \text { from this study, the clauses } \\ & \text { that are spoken reflect the } \\ & \text { speaker's gratification. This } \\ & \text { sentence is included in the } \\ & \text { direction because it } \\ & \text { demands the listener, with } \\ & \text { the speaker demanding that } \\ & \text { the sun rotates with its own } \\ & \text { axis, so the speaker demands }\end{aligned}$


who can explain 1400 years

ago in the Quran.

3. Commisive

Dr. Zakir Naik's speech in the form of commisive was described in the below:

Table 4.

Commisive Classification and Function of Dr. Zakir Naik's Speech

\begin{tabular}{|c|c|c|c|c|}
\hline No & Speech & Form & Function & Note \\
\hline 1 & $\begin{array}{l}\text { The atheist may say: } \\
\text { Your prophet } \\
\text { Mohammad peace } \\
\text { upon him, maybe he } \\
\text { was an intelligent } \\
\text { man. }\end{array}$ & Commisive & Praising & $\begin{array}{l}\text { Researchers also find the } \\
\text { commisive (Praising) that } \\
\text { appears in the clause "Your } \\
\text { Prophet, Mohammad, peace } \\
\text { be upon him, maybe he is an } \\
\text { intelligent person." In the } \\
\text { researcher's opinion, the } \\
\text { pronounced clause reflects } \\
\text { the praise of someone atheist } \\
\text { to the prophet. }\end{array}$ \\
\hline 2 & $\begin{array}{l}\text { Again the atheist may } \\
\text { say: you know your } \\
\text { prophet maybe too } \\
\text { point intelligently. }\end{array}$ & Commisive & Praising & $\begin{array}{l}\text { Researchers also find the } \\
\text { commisive (Praising) that } \\
\text { appears in the clause " Again } \\
\text { the atheist may say: you } \\
\text { know your prophet maybe } \\
\text { too point intelligently." In } \\
\text { the researcher's opinion, the } \\
\text { pronounced clause reflects } \\
\text { the praise of someone atheist } \\
\text { to the prophet. }\end{array}$ \\
\hline
\end{tabular}

4. Declarative

Dr. Zakir Naik's speech in the form declarative was described in the below:

Table 5.

Declarative Classification and Function of Dr. Zakir Naik's Speech

\begin{tabular}{|c|c|c|c|c|}
\hline No & Speech & Form & Function & Note \\
\hline 1 & $\begin{array}{l}\text { Don't argue with him, } \\
\text { continue... }\end{array}$ & Declarative & Prohibiting & $\begin{array}{l}\text { The researcher also found } \\
\text { the declarative that appeared } \\
\text { in the sentence "Don't argue } \\
\text { with him, continue..." In the } \\
\text { opinion of the researchers, } \\
\text { the research is a clause that is } \\
\text { spoken reflecting prohibiting } \\
\text { debate. }\end{array}$ \\
\hline 2 & $\begin{array}{l}\text { Don't argue with him } \\
\text {.. you can continue... }\end{array}$ & Declarative & Prohibiting & $\begin{array}{l}\text { The researcher also found } \\
\text { the declarative that appeared } \\
\text { in the sentence "Don't argue } \\
\text { with him ... you can } \\
\text { continue..." In the opinion of } \\
\text { the researchers, the research } \\
\text { is a clause that is spoken }\end{array}$ \\
\hline
\end{tabular}




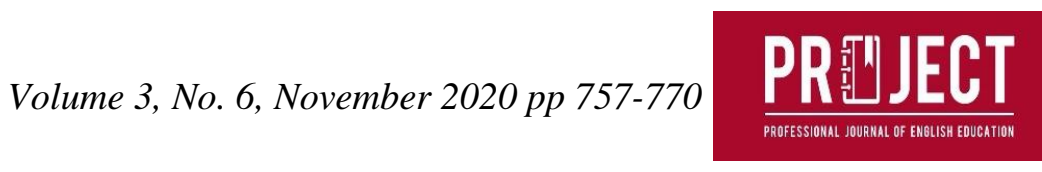

reflecting

prohibiting

debate.

\section{CONCLUSION}

From the results of data analysis, found 13 representative forms, 7 directives, commisive 2, no expressive form and 2 declarative form. The form of Representative utterance is the dominant form in Dr. Zakir Naik's utterances. This is following the context in which the questioner asks for the confusion he gets. In terms of function, affirming, informing, and disputing is the most dominant. Dr. Zakir Naik gives confirmation, explanation, and refutation in a conducive context.

\section{ACKNOWLEDGMENTS}

By giving thanks to the presence of Allah SWT who has bestowed His grace and gifts so that the author can complete this article, entitled "Speech Act Dr. Zakir Naik's Speech on YouTube Channel Sadnex1: Does God Exist ". Through this writing, the author realizes that the ability and experience of the writer are very limited, the author realizes that the ability and experience of the writer are very limited, so in the preparation of writing this paper there are any shortcomings or weaknesses. the author hopes and appreciates suggestions and constructive criticism, both for improving the writing of this paper and avoiding the same mistakes in the future. From the beginning to the end of this paper, the authors get a lot of moral and material assistance in the form of teaching, guidance, instructions, and facilities needed in this writing. Therefore, with all humility, the author would like to express his gratitude to Mr. Iman Santoso, S. Pd., M. Hum., as a mentor, Both beloved parents Mr. H Dadan Kuswana (Alm), Mrs. Nina Khaerani, sister Novindasari Munawarah Umar, brother Irfan Al Hasyimi, and little brother Abdillah Umar who always gives love, attention, moral support, material and opportunities to the writer, so that this writing can be resolved, friends of the writer Agus Mauludin, Bila Aprilia, Elba Paradisa, Fahmi Nurfiqri, Pia Apiyati Barkah, Sofa Lutfia Azzahra, Sundari Novemberiani Dwi Aktari Sultan who always gave full encouragement and support to the author until the completion of this writing. Finally, I was a researcher to expect and need more constructive criticism and suggestions from readers to make this paper more perfect.

\section{REFERENCES}

Andriyani, S. (2016). Linguistics and Applied Linguistics. Jurnal Edulingua, 3(1), 2015-2016. Kiuk, P. Y., \& Ghozali, I. (2018). Speech Acts Analysis in Desmond's Conversation in "Hacksaw Ridge" Movie Paswasari. Journal of English Language and Language Teaching (JELLT), 2(1), 59-72.

Moleong, L. J. (2017). Metodologi Penelitian Kualitatif (Edisi Revisi). In Bandung: Remaja Rosdakarya. Retrieved From Https://Rosda.Co.Id/Pendidikan-Keguruan/486Metodologi-Penelitian-Kualitatif-Edisi-Revisi.Html

Mufiah, N. S., Yazid, M., \& Rahman, N. (2018). Speech Acts Analysis of Donald Trump ' S Speech. Journal of English Education, 1(2), 125-132. Retrieved From Https://Journal.Ikipsiliwangi.Ac.Id/Index.Php/Project/Article/Download/461/67

Praditya, Dwi Jaya I Made, Putra, A. J. I. N., \&, Artini, L. P. (2014). An Analysis of Speech Acts in the Conversation Between Habibie and Ainun in the Film Entitled Habibie and Ainun 2012. Journal of English Education Department, Postgraduate Program Ganesha University Of Education Singaraja, Indonesia, 2(1), 1-10. 
Richards, J. C., \& Schmidt, R. (2010). Dictionary of Language Teaching \& Applied Linguistics.

London :

Longman.

Retrieved

From

Http://Search.Ebscohost.Com/Login.Aspx?Direct=True\&Db=Lah\&An=20163298076\&

Site $=$ Ehost -

Live\%0ahttp://Www.Cabi.Org/Cabdirect/Showpdf.Aspx?Pan=Http://Www.Cabi.Org/Ca bdirect/Showpdf.Aspx?Pan=20163298076\%0aemail: Javaidleghari@ Hotmail.Com

Santoso, I., Sujatna, E. T. S., \& Mahdi, S. (2014). Speech Act on Short Stories; A Pragmatic Study. The International Journal of Social Sciences, 19(1), 108-118. Retrieved From Https://Www.Tijoss.Com/19 Volume/10imam Santoso.Pdf

Searle, J. R. (1997). Reiterating The Differences: A Reply To Derrida. Baltimore: Johns Hopkins University Press, 1. Retrieved From Https://Id.Scribd.Com/Document/183400109/95908042-Searle-John-1977-ReiteratingThe-Differences-A-Reply-To-Derrida-Scan

Tutuarima, Z., Nuraeningsih, \& Rusiana. (2018). An Analysis of Speech Act Used in London Has Fallen Movie. Vision: Journal For Language And Foreign Language Learning, 7(2), 160-169.

Wijaya, F. R., \& Helmie, J. (2019). An Analysis of Directive Speech Acts in The Fault in Our. Journal of English Pedagogy, Linguistics, Literature, And Teaching, 7(1).

Wulan, A. P. (2011). Mobil Dalam Harian Umum Solopos ( Edisi 21 Juni 2011 ). Jurnal Pendidikan Bahasa, 2(2), 149-164.

Wulandari, Agustina, \& Ngusman. (2015). Tindak Tutur Ekspresif Mario Teguh Dalam Acara "Golden Ways." Bahasa, Sastra Dan Pembelajaran, 2(1), 99-113. Retrieved From Http://Jurnal.Unimed.Ac.Id/2012/Index.Php/Ajs/Article/View/3904

Yule, G. (1996). Pragmatics. In New York: Oxford University Press (P. 3). 